\title{
Penegakan Hukum terhadap Tindak Pidana Perjudian Toto Gelap
}

\section{Law Enforcement against the Crime of Illegal Toto Gambling}

\author{
Natanail Sitepu, Isnaini* \& Citra Ramadhan \\ Program Magister Ilmu Hukum, Universitas Medan Area, Indonesia \\ Diterima: 02 Agustus 2021; Direview: 03 Agustus 2021; Disetujui: 30 September 2021
}

*Coresponding Email:isnaini@staff.uma.ac.id

\begin{abstract}
Abstrak
Penelitian ini bertujuan untuk menganalisis aturan hukum mengenai tindak pidana perjudian menganalisis faktor apa yang mendorong terjadinya tindak pidana perjudian toto gelap, khususnya di Kabupaten Deli Serdang. Adapun Metode penelitian yang digunakan adalah metode deskriptif, dengan pendekatan kasus dan perundang-undangan, dengan instrument pengumpulan data wawancara dan studi dokumentasi, sedangkan teknik analisis data menggunakan deskriptif kualitatif. Hasil penelitian menunjukkan pengaturan hukum terhadap judi togel didasarkan pada pasal 303 KUHP dan pasal 303 bis dan UU UTE pasal 27 ayat (2), dengan ancaman pidana pada pasal 45 ayat (2), serta Undang-Undang No. 7 Tahun 1974 tentang Penertiban Perjudian pada Pasal 1 bahwa perjudian dalam bentuk apapun merupakan suatu kejahatan. Faktor-faktor yang mendorong terjadinya tindak pidana perjudian di Kabupaten Deli Serdang adalah: adanya harapan mendapatkan kemenangan, adanya pengaruh lingkungan, judi togel mudah dilakukan oleh semua orang, tidak membutuhkan waktu banyak untuk melakukannya, juru tulis togel tersedia di banyak tempat, perkembangan teknologi informasi memudahkan pemain mengirimkan tebakan angka judi togel, serta lemahnya pengawasan oleh aparat kepolisian. Penegakan hukum terhadap perjudian jenis togel di Pengadilan Negeri Lubuk Pakam masih kurang tegas.
\end{abstract}

Kata Kunci: Penegakan Hukum; Tindak Pidana; Perjudian Toto Gelap.

\begin{abstract}
This study aims to analyze the legal rules regarding the crime of gambling to analyze what factors encourage the occurrence of illegal toto gambling crimes, especially in Deli Serdang Regency. The research method used is descriptive method, with a case approach and legislation, with interview data collection instruments and documentation studies, while the data analysis technique uses qualitative descriptive. The results of the study show that the legal regulation of lottery gambling is based on article 303 of the Criminal Code and article 303 bis and the UTE Law article 27 paragraph (2), with criminal threats in article 45 paragraph (2), as well as Law no. 7 of 1974 concerning Gambling Control in Article 1 that gambling in any form is a crime. The factors that encourage the occurrence of gambling crimes in Deli Serdang Regency are: the hope of getting a win, the influence of the environment, lottery gambling is easy for everyone to do, it doesn't take much time to do it, lottery clerks are available in many places, the development of information technology make it easier for players to send guesses for lottery gambling numbers, as well as weak supervision by the police. Law enforcement against lottery type gambling at the Lubuk Pakam District Court is still not firm.
\end{abstract}

Keywords: Law Enforcement; Crime; Illicit Toto Gambling.

How to Cite: Sitepu, N., Isnaini, \& Ramadhan, M.C. (2021). Penegakan Hukum Terhadap Tindak Pidana Perjudian Toto Gelap. Journal of Education, Humaniora and Social Sciences (JEHSS). 4 (2): 1199-1208. 


\section{PENDAHULUAN}

Terdapat banyak jenis pelanggaran hukum, tetapi yang paling marak terjadi adalah pelanggaran terhadap larangan perjudian dengan harapan mendapat keuntungan sesaat dalam jumlah besar. Walaupun pemerintah telah melakukan sosialisasi yang gencar mengenai larangan perjudian tetapi masyarakat seakan tidak perduli dengan semua larangan dan pidana yang diancamkan. Sanksi pidana perjudian sebenarnya sudah tergolong berat tetapi pelakunya di tengah-tengah masyarakat tetap banyak dan bahkan mengalami peningkatan pada setiap tahun. Perjudian telah menjadi penyakit sosial di masyarakat yang tergolong sulit untuk disembuhkan.

Dalam Kitab Undang-Undang Hukum Pidana (selanjutnya disebut KUHP) Pasal 303 ayat (3) mengartikan judi adalah tiap-tiap permainan yang mendasarkan pengharapan untuk menang, pada umumnya bergantung kepada untung-untungan. Judi adalah pertaruhan tentang keputusan perlombaan atau permainan lain yang tidak diadakan oleh mereka yang turut berlomba atau bermain itu, demikian juga segala permainan lainnya. Jika, melihat Pasal 303 ayat (3) dapat dipersepsikan bahwa unsur utama dari judi adalah untung-untungan yang juga ada pakar menyebut tergantung nasib.

Beberapa jenis perjudian yang marak dimainkan di Indonesia adalah domino, poker, sports, live casino, sabung ayam, dan toto gelap yang sering disebut dengan 'judi togel'. Tetapi dari sekian banyak jenis judi, toto gelap merupakan jenis perjudian yang sangat banyak diminati oleh masyarakat. Jenis judi toto gelap diminati secara khusus oleh masyarakat dari golongan ekonomi rendah, baik di perkotaan maupun di daerah pedesaan. Peminatnya tidak hanya dari kalangan bapak-bapak, tetapi juga diminati oleh ibu-ibu, serta anak-anak muda. Banyaknya peminat judi togel dari berbagai kalangan termasuk ibu rumah tangga disebabkan teknik bermainnya yang sangat sederhana, yaitu hanya dengan menebak angka, yaitu dari angka dua digit hingga angka empat digit, serta tidak membutuhkan banyak waktu sehingga dianggap tidak mengganggu pekerjaan. Penebakan angka pun dapat dilakukan dengan mudah, mulai dari melihat kejadian (gejala) alam sampai tafsir mimpi menggunakan 'kode erek-erek' serta dengan metode lainnya. Demikian juga dengan pemesanan tidak lagi harus dilakukan secara langsung dengan mendatangi penulis togel atau pun bandar, tetapi dapat dipesan melalui handphone yang telah dimiliki oleh sebagian besar orang. Judi togel telah menjadi semacam budaya ditengah masyarakat, khususnya masyarakat pelosok desa yang jauh dari jangkauan atau pengawasan aparat penegak hukum, sehingga menyebabkan permainan jenis judi toto gelap atau togel berkembang pesat dan semakin sulit dikendalikan hingga sekarang.

Penegakan hukum terhadap judi togel didasarkan pada pasal 303 KUHP dan pasal 303 bis, serta undang-undang nomor 7 tahun 1974 tentang penertiban perjudian. Sementara penegakan hukum terhadap perjudian online dilakukan berdasarkan UU Informasi dan Transaksi Elektronik yang disingkat dengan UU ITE. Pasal 303 bis ayat (1) KUHP, berbunyi:

Diancam dengan kurungan paling lama 4 (empat) tahun atau denda paling banyak sepuluh juta rupiah: barangsiapa menggunakan kesempatan untuk main judi, yang diadakan dengan melanggar peraturan pasal 303; barangsiapa ikut serta permainan judi yang diadakan di jalan umum atau di pinggirnya maupun di tempat yang dapat dimasuki oleh khalayak umum, kecuali jika untuk mengadakan itu, ada izin dari penguasa yang berwenang.

Sementara mengenai perjudian online sebagai perbuatan yang dilarang diatur dalam Pasal 27 ayat (2) UU ITE yang berbunyi: Setiap Orang dengan sengaja dan tanpa hak mendistribusikan, mentransmisikan, dan/atau membuat dapat diaksesnya Informasi atau Dokumen Elektronik yang memiliki muatan

Ancaman pidana terhadap perjudian online diatur dalam Pasal 45 ayat (2) UU 19/2016, yakni: Setiap Orang yang dengan sengaja dan tanpa hak mendistribusikan dan/atau mentransmisikan dan/atau membuat dapat diaksesnya Informasi Elektronik dan/atau Dokumen Elektronik yang memiliki muatan perjudian sebagaimana dimaksud dalam Pasal 27 ayat (2) dipidana dengan pidana penjara paling lama 6 (enam) tahun dan/atau denda paling banyak Rp 1 miliar.

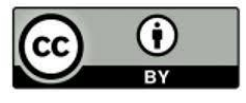


Tetapi dalam prakteknya, penegakan hukum terhadap pelaku perjudian toto gelap belum dilakukan secara tegas sehingga tindak pidana perjudian di tengah masyarakat tetap marak terjadi, bahkan semakin berkembang seiring dengan perkembangan teknologi online. Sebagian besar terdakwa pelaku perjudian toto gelap dipidana dengan pidana penjara kurang dari 1 tahun, dan terdapat juga beberapa pelaku yang dipidana hanya dengan pidana ringan (kurang dari 3 bulan penjara), bahkan terdapat juga tersangka yang sengaja dilepaskan pada tingkat penyidikan.

Salah satu tindak pidana judi togel yang dipidana dengan pidana ringan adalah atas nama terdakwa Porman Turnip, SH dalam Putusan No. 348/Pid.B/2020/PN.Lbp. Tetapi majelis hakim yang mengadili perkara tersebut menjatuhkan pidana yang sangat ringan, yaitu 1 bulan dan 6 hari penjara, jauh di bawah ancaman pidananya.

Hasil penelitian Rito Priasmoro (2016) dengan judul Peran Kepolisian Dalam Penanggulangan Tindak Pidana Perjudian Koprok (Studi Kasus di Wilayah Hukum Polres Metro), diperoleh bahwa Peran kepolisian dalam penanggulangan tindak pidana perjudian koprok, Polri sebagai kekuatan hukum untuk pembinaan masyarakat yang melakukan tindakan pidana sesuai dengan melakukan fungsi sesuai Pasal 2, tugas sesuai Pasal 13, dan wewenang sesuai Pasal 15 mencakup Undang-Undang Nomor 2 Tahun 2002 tentang Kepolisian Negara Republik Indonesia, baik dilakukan secara penal dan juga non penal. Peranan lebih banyak menunjukkan suatu peranan. Sehubungan dengan itu, terdapat juga faktor penghambat yaitu adanya pembackingan oleh aparat penegak hukum tentu yang menyalahgunakan kewenangannya. Polres Kota Metro selalu saja menemukan aparat yang menjadi pembackingan tersebut dalam setiap operasi mereka. Bahkan tidak jarang para pembackingan tersebut sangat berani melawan petugas polisi pada saat penggrebekan berlangsung.

Hasil penelitian Angga Adi Saputra (2013) dengan judul Upaya Kepolisian Dalam Menganggulangi Tindak Pidana Perjudian di Wilayah Hukum Polres Boyolali, diperoleh bahwa Bentuk perjudian yang dilakukan oleh masyarakat di wilayah hukum Polres Boyolali yaitu ada 6 (enam) jenis, dengan berbagai modus operandi atau permainan perjudian yang berbeda-beda diantaranya dengan menggunakan kupon, dadu, kartu atau langsung dengan menyerahkan taruhannya. Adapun modus operandinya berupa berpura-pura membuka warung makanan ataupun warung kopi, melakukan permainan judi di tempat terpencil serta melakukan permainan judi pada acara hajatan. Upaya-upaya yang sering dilakukan oleh Polres Boyolali di dalam mengungkap modus operandi yang dijalankan oleh para pelaku tindak pidana perjudian diantaranya adalah melakukan upaya preventif dan represif. Upaya preventif dilakukan dengan memberikan penyuluhan kepada masyarakat dengan melakukan sosialisasi dan penyuluhan kepada masyarakat yang kurang mengerti akan dampak negatif dari perjudian, sedangkan upaya represif dilakukan dengan penyelidikan dan mencari informasi dari masyarakat mengenai daerah-daerah yang disinyalir sebagai tempat yang rawan akan tindak pidana perjudian, melakukan operasi atau razia ditempat-tempat keramaian. Kendala-kendala yang dialami oleh pihak Polres Boyolali didalam mengungkap modus operandi tindak pidana perjudian, antara lain : masih banyaknya masyarakat yang menyukai perjudian, kurangnya kepedulian dan partisipasi masyarakat dalam memberikan informasi mengenai perjudian, semakin rapinya modus operandi yang dijalankan oleh para pelaku tindak pidana perjudian, terbatasnya atau kurangnya personil untuk melakukan operasi maupun razia dan ditambah pula dengan kurangnya dukungan sarana yang dimiliki oleh pihak kepolisian.Berdasarkan dari penelitian diatas maka tujuan penelitian, Untuk mengkaji dan menganalisis aturan hukum mengenai tindak pidana perjudian.faktor yang mendorong terjadinya tindak pidana perjudian toko gelap di Kabupaten Deli Serdang.

\section{METODE PENELITIAN}

Jenis penelitian yang digunakan dalam penulisan tesis ini adalah metode penelitian yuridis normatif bersifat deskriptif analisis, yaitu penelitian yang dilakukan dengan cara meneliti bahan pustaka (data sekunder) atau penelitian hukum perpustakaan (Ediwarman 2016). Penelitian hukum normatif merupakan suatu prosedur penelitian ilmiah untuk menemukan kebenaran berdasarkan logika keilmuan hukum dari sisi normatifnya. Logika keilmuan yang sering dipakai 
dalam penelitian hukum normatif yaitu ilmu hukum yang objeknya hukum itu sendiri. Penelitian hukum normatif terdiri dari: Asas hukum regulatif (yang sejajar dengan pembedaan menjadi asas hukum umum dan asas hukum khusus); Asas hukum konsitutif merupakan asas-asas yang harus ada dalam kehidupan suatu sistem hukum (Ibrahim, 2006).

Metode sangat penting dalam sebuah penelitian. Metode pendekatan yang digunakan dalam penelitian ini adalah: Metode pendekatan kasus (case approach) yaitu dengan cara menganalisis Putusan Nomor No. 348/Pid.B/2020/PN.Lbp. Metode pendekatan perundangundangan (statute approach) yaitu dilakukan dengan menelaah ketentuan perundang-undangan yang berlaku dalam kasus tersebut yaitu Kitab Undang-Undang Hukum Pidana (KUHP), dan Kitab Undang-Undang Hukum Acara Pidana (KUHAP).

Penelitian ini menggunakan bahan yang diperoleh dari hasil penelitian kepustakaan (library research) yang sudah dikumpulkan. Untuk data sekunder meliputi: Bahan hukum primer, yaitu bahan-bahan hukum yang mengikat seperti peraturan perundang-undangan, yurisprudensi, traktat, dan lainya yang berkaitan dengan Penegakan Hukum terhadap Tindak Pidana Perjudian Toto Gelap (Studi Putusan No. 348/Pid.B/2020/PN.Lbp). Dalam penelitian ini adalah: Undang-Undang Republik Indonesia Nomor 2 Tahun 2002 Tentang Kepolisian Negara Republik Indonesia; Kitab Undang-Undang Hukum Pidana (KUHP); Kitab Undang-Undang Hukum Acara Pidana (KUHAP).

Bahan hukum sekunder, yaitu bahan hukum yang memberikan penjelasaan mengenai bahan hukum primer seperti Undang-undang kekuasaan kehakiman dan bahan bacaan yang relevan. Bahan tersier, yaitu bahan hukum yang memberikan petunjuk maupun penjelasan terhadap bahan hukum primer dan bahan hukum sekunder seperti kamus dan literatur-literatur ilmu pengetahuan hukum yang berkaitan dengan perdata serta keterangan-keterangan yang mendukung bahan hukum primer dan bahan hukum sekunder.

Teknik yang dipergunakan untuk pengumpulan data atau bahan hukum dalam penelitian ini adalah: Observasi yaitu pengamatan langsung di lapangan kegiatan masyarakat yang menyangkut tindak pidana perjudian toto gelap; Studi dokumentasi yaitu teknik pengumpulan data dengan menggunakan catatan-catatan atau dokumen yang ada di lokasi penelitian serta sumber-sumber lain yang relevan dengan objek penelitian; Wawancara langsung dengan pihak yang bertanggung jawab dan terkait langsung dalam penegakan hukum terhadap tindak pidana perjudian toto gelap, agar diperoleh gambaran mengenai proses penegakan hukumnya. Informannya terdiri dari: Komisaris Polisi Muhammad Firdaus selaku Kepala Reskrim Polresta Deli Serdang, Lenny Lasminar S, S.H., M.H selaku Hakim pada Pengadilan Negeri Medan dan Marsal Tarigan, S.H., M.H. selaku Hakim pada Pengadilan Negeri Medan.

Analisis data dalam penelitian ini adalah secara kualitatif. Data primer yang diperoleh dari hasil penelitian yang disusun sedemikian rupa kemudian dianalisis secara deskriptif, logis dan sistematis yang dinyatakan oleh pihak terkait secara lisan dan dituangkan secara tertulis, serta dikaitkan data sekunder dengan menggunakan metode berfikir, deduktif, dan induktif yang berpedoman pada hukum pidana dan perundang-undangan yang berhubungan dengan permasalahan yang diteliti untuk menjawab permasalahannya.

\section{HASIL DAN PEMBAHASAN}

\section{Aturan Hukum Mengenai Tindak Pidana Perjudian di Indonesia}

Perjudian secara tegas dinyatakan sebagai kejahatan terhadap kesopanan didalam KUHP, sehingga para pelakunya dapat dikenai suatu sanksi pidana. Dalam Kamus Besar Bahasa Indonesia (KBBI), yang dimaksud dengan "judi" adalah permainan yang memakai uang/barang berharga sebagai taruhan (seperti main dadu, kartu).

Sedangkan yang dimaksud dengan berjudi adalah: 1.Mempertaruhkan sejumlah uang/harta dalam permainan tebakan berdasarkan kebetulan dengan tujuan mendapatkan sejumlah uang atau harta yang lebih besar daripada jumlah uang/harta semula; 2 . Bermain dadu (kartu atau sebagainya) dengan taruhan uang/harta.

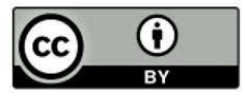


Dalam Undang-Undang Nomor 7 Tahun 1974 Tentang Penertiban Perjudian, tidak ada penjelasan secara detail defenisi dari perjudian. Namun dalam Undang-Undang Nomor 1 Tahun 1946 Tentang Kitab Undang-Undang Hukum Pidana (KUHP). Pasal 303 ayat (3) berbunyi :

"Yang dimaksud dengan permainan judi adalah tiap-tiap permainan, dimana kemungkinan untuk menang pada umumnya bergantung pada peruntungan belaka, juga karena pemainnya lebih terlatih atau lebih mahir, dalam pengertian permainan judi termasuk juga segala pertaruhan tentang keputusan perlombaan atau permainan lainnya yang tidak diadakan antara mereka yang turut berlomba atau bermain, demikian juga segala pertaruhan lainnya."

Dari rumusan diatas sebenarnya ada dua pengertian perjudian, yaitu: Suatu permainan yang kemungkinan mendapat untung bergantung pada peruntungan atau nasib belaka. Pada jenis perjudian ini, menang atau kalah dalam arti mendapat untung atau rugi hanyalah bergantung pada keberuntungan saja atau secara kebetulan saja, misalnya dalam permainan judi dengan menggunakan dadu; Permainan yang kemungkinan mendapatkan untung atau kemenangan sedikit banyak bergantung pada kepandaian dan kemahiran pemainnya. Misalnya permainan melempar bola, permainan memanah, bermain bridge atau domino (Charzawi, 2005).

Dua pengertian perjudian diatas, diperluas juga pada dua macam pertaruhan, yaitu: Segala bentuk pertaruhan tentang keputusan perlombaan lainnya yang tidak diadakan oleh mereka yang turut berlomba atau bermain; Segala bentuk pertaruhan lainnya yang tidak ditentukan. Dengan kalimat yang tidak menentukan bentuk pertaruhan secara limitatif, maka segala bentuk pertaruhan dengan cara bagaimana pun dalam segala hal manapun adalah termasuk perjudian. Seperti beberapa permainan kuis untuk mendapatkan hadiah yang ditayangkan di televisi termasuk juga perjudian dalam Pasal ini.

Tetapi permainan kuis itu tidak termasuk permaina judi yang dilarang karena bersifat hiburan dan telah mendapat izin dari pihak yang berwenang. Pada dasarnya perjudian adalah permainan dimana adanya pihak yang saling bertaruh untuk memilih satu pilihan diantara beberapa pilihan, dimana hanya ada satu pilihan saja yang benar dan menjadi pemenang. Pihak yang kalah taruhan akan memberikan taruhannya kepada pihak pemenang. Peraturan dan jumlah taruhan ditentukan sebelum pertandingan atau permainan dimulai. Terkait dengan perjudian banyak negara yang melarang perjudian sampai taraf tertentu. Terutama negara Islam melarang perjudian dan hampir semua Negara mengatur itu. Kebanyakan hukum negara tidak mengatur tentang perjudian, dan memandang sebagai akibat dari konsekuensi masing masing, serta tidak dapat dilaksanakan oleh proses yang sah sebagai undang-undang.

\section{Faktor yang Mendorong Terjadinya Tindak Pidana Perjudian Toto Gelap di Kabupaten Deli Serdang}

Togel merupakan singkatan dari Toto Gelap, yaitu merupakan aktivitas permainan semacam lotre di Singapura. Togel atau toto gelap adalah jenis judi yang dilakukan dengan menebak angka secara tersembunyi. Tersembunyi yang dimaksud adalah tidak ada petunjuk dan benar-benar murni menebak. Keluaran angka yang nantinya muncul pada hasil togel menjadi penentu siapa pemenangnya.

Perjudian toto gelap di Kabupaten Deli Serdang juga belakangan ini semakin marak terjadi. Maraknya tindak pidana tersebut karena perjudian tidak sulit dilakukan, dan sangat menyenangkan bagi semua pihak yang turut melakukannya, dengan harapan akan menang dan memperoleh keuntungan sesaat dalam jumlah besar. Tetapi tanpa disadari pada dasarnya togel telah banyak merugikan masyarakat. Omset perjudian togel dalam suatu daerah relatif besar dibanding jenis judi lainnya. Walaupun harga per lembar hanya Rp. 1.000, tetapi masyarakat yang mengikutinya sangat banyak, dan banyak juga diantaranya yang merupakan pecandu togel. Sebagai pecandu togel, maka dia akan memasang taruhan dalam jumlah besar dengan membeli banyak lembaran togel sehingga uang yang dikeluarkannya cukup banyak. Menurut Kartono bahwa perjudian adalah pertaruhan dengan sengaja yang mempertaruhkan satu nilai atau sesuatu yang dianggap bernilai dengan menyadari adanya risiko dan harapanharapan tertentu 
pada peristiwa-peristiwa permainan, pertandingan, perlombaan dan kejadian-kejadian yang tidak atau belum pasti hasilnya (Kartono, 2005).

Pengeluaran untuk judi yang relatif besar tentu akan berpengaruh negatif terhadap ekonomi keluarga, terutama bagi keluarga golongan bawah atau miskin. Dampak negatif dari peredaran judi togel akan sangat terasa bagi keluarga miskin, padahal banyak diantara penebak togel adalah warga miskin baik di kota maupun daerah pedesaan, dengan harapan agar cepat dapat modal untuk kaya, padahal belum pernah ada yang kaya karena togel kecuali bandarnya. Kalangan warga miskin justru semakin terganggu perekonomiannya karena adanya biaya tambahan untuk menebak togel, sedangkan memenuhi kebutuhan hidup sehari-hari pun sudah mengalami kesulitan. Akan tetapi ketidakmampuan mereka dalam memenuhi kebutuhan hidup mendorongnya untuk melakukan tindak kriminalitas sebagai jalan pintas untuk merubah hidupnya. Perjudian togel merupakan salah satu bentuk kriminalitas yang dipilih masyarakat untuk membantu mereka keluar dari kesulitan ekonomi (Soetomo, 2013). Dampak negatif lebih lanjut adalah menimbulkan persoalan atau percencokan dalam rumah tangga. Judi togel juga berdampak negative karena menimbulkan persoalan dalam rumah tangga antara suami istri. Hal ini karena suami sering memasang taruhan togel padahal untuk makan saja sulit. Bahkan lebih buruk lagi bagi pecandu togel yang rela meminjam uang kepada teman atau tetangga untuk memasang taruhan, karena merasa punya harapan besar bahwa dianya akan menang taruhan, walaupun beberapa kali sebelumnya bahwa dugaan atau harapan menangnya tidak tercapai. Banyak pasangan suami istri yang cekcok berat karena togel sehingga terjadinya perceraian.

Tetapi perjudian tidak hanya sebatas menimbulkan kerugian keuangan bagi masyarakat, tetapi juga sering menyita pikiran ataupun perhatian terutama bagi pecandu togel. Judi togel juga dapat mengganggu aktivitas masyarakat, karena perhatian mereka banyak tertuju pada angka berapa yang akan dipasang taruhan, yaitu dengan melihat dan memperhatikan kejadian-kejadian yang mereka anggap aneh di sekitar mereka, dan menterjemahkannya dengan angka pada ereketek, sehingga memecah perhatian mereka dari pekerjaan sehari-hari. Bahkan lebih buruk lagi bagi pecandu judi togel yang sering duduk berjam-jam di kedai untuk membahas angka tebakan, dengan mengabaikan pekerjaan dan membiarkan istri dan anak-anak menangani pekerjaan keluarga. Padahal sebenarnya belum pernah ada masyarakat yang benar-benar berhasil dari perjudian toto gelap. Harapan masyarakat khususnya pecandu togel untuk kaya mendadak hanyalah harapan yang dibangunnya sendiri di alam pikirannya, karena fakta di lapangan menunjukkan belum pernah ada orang menjadi kaya mendadak karena menang taruhan togel. Beberapa orang yang menang taruhan tetapi jumlah kemenangannya kecil dan masih tidak sebanding dengan uang yang telah dikeluarkan sebelumnya dalam memasang taruhan. Informan menyatakan bahwa yang benar-benar menikmati kemenangan dari togel hanyalah bandar judinya yang terlihat semakin kaya.

\section{Faktor yang Mendorong Terjadinya Tindak Pidana Perjudian Toto Gelap}

Harapan Mendapatkan Kemenangan, Salah satu faktor yang menyebabkan banyaknya peminat judi togel adalah tingginya pengharapan masyarakat untuk memenangkan taruhan, yang disertai dengan keyakinan bahwa angka taruhannya pasti berhasil menang. Pemain judi togel selalu menganggap bahwa dia akan berhasil memenangkan taruhan, dengan keyakinan bahwa angka yang dipasangnya telah benar-benar tepat dengan angka yang akan keluar. Sedangkan bagi para pecandu justru berharap suatu saat akan menang sehingga dia akan selalu berusaha dengan sungguh-sungguh menganalisis angka berapa yang akan dipasang pada setiap hari. Dengan demikian bahwa alasan yang paling kuat dari penjudi togel adalah adanya harapan akan mendapatkan uang banyak, terlebih jumlah hadiah yang ditawarkan bagi pemenang juga relatif besar jika dibanding dengan biaya per lembar tebakan togel yang dibayarkan oleh penjudi. Menurut Ritzer bahwa masyarakat tidak begitu menghiraukan karena sulitnya mencari pekerjaan dan uang yang dimiliki tidak mencukupi, sehingga mereka malas berusaha. Karena lokasi lingkungan akhirnya mereka menganggap bermain judi togel tersebut merasa tertolong dan dapat membantu dalam mendapatkan uang dengan mudah (Ritzer, 2009).

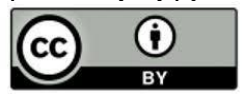


Pengaruh Lingkungan. Lingkungan juga merupakan faktor yang berpengaruh terhadap semakin maraknya permainan judi togel. Pengaruh lingkungan tersebut khususnya terjadi akibat adanya ajakan dari kawan, atau banyak orang di lingkungan yang memasang taruhan, atau bahkan ada yang memenangkan taruhan. Pengaruh lingkungan, baik teman atau tetangga maupun lingkungan yang lebih besar memiliki pengaruh besar terhadap perilaku masyarakat dalam berjudi. Ajakan teman atau tetangga untuk memasang taruhan akan mendorong untuk bermain judi togel, demikian juga dengan lingkungan masyarakat yang dominan bermain togel akan mendorong orang-orang memasang taruhan togel. Terlebih jika terdapat orang yang memenangkan taruhan maka hal tersebut akan memacu semangat orang-orang untuk terus memasang taruhan togel, dimana biasanya berita orang yang menang taruhan akan tersebar ke seluruh penjuru lingkungan karena orangnya memang secara sengaja membanggakan diri sebagai pemenang.

Judi Togel Mudah Dilakukan. Judi togel merupakan jenis judi yang tergolong mudah dilakukan oleh siapa saja. Hal ini karena orang-orang hanya perlu menebak angka berapa yang akan keluar, yang dapat diduga-duga hanya dengan melihat gejala alam atau bertanya kepada teman. Bermain judi togel sangat mudah untuk dilakukan karena tidak membutuhkan keahlian khusus sebagaimana judi lainnya yang terlebih dahulu harus belajar. Caranya hanya menebak angka, dimana sumber angka dapat berasal dari teman, atau dengan mencari sendiri. Banyak orang khusunya ibu-ibu mengandalkan kejadian di lingkungan sekitar sebagai sumber angka tebakan, atau juga berasal dari mimpi, baik mimpi sendiri maupun mimpi tetangga sebelah. Demikian mudahnya bermain judi togel sehingga ibu-ibu pun bisa mengikutinya tanpa harus belajar terlebih dahulu.

Tidak Membutuhkan Waktu Banyak. Judi togel tidak harus menyita waktu sebagaimana jenis judi lainnya yang harus terlibat secara langsung dari awal mulai hingga selesainya perjudian. Judi togel dapat berjalan atau diikuti sambil berjalannya waktu kerja. Pemain judi togel sangat dipermudah dengan tidak adanya waktu khusus yang diperlukan dalam mengikuti judi togel, sebagimana misalnya judi kartu. Hanya sebagian kecil orang yang mau spesial menggunakan waktunya untuk membahas angka togel, sedangkan sebagian besar lainnya memperkirakan angka tebakan sambil bekerja, dimana hal tersebut tidak terlalu mengganggu bagi mereka yang umumnya bekerja sebagai pedagang ataupun petani desa.

Juru Tulis Tersedia di Banyak Tempat. Faktor pendorong lainnya yang menyebabkan semakin maraknya judi togel adalah kemudahan pemesanan angka, karena juru tulis (jurtul) tersedia di banyak tempat di lingkungan masyarakat. Masyarakat pemain judi togel juga dimudahkan dengan ketersediaan juru tulis di berbagai tempat yang menerima pesanan masyarakat, sehingga masyarakat tidak perlu jauh-jauh dalam melakukan pemesanan. Banyak orang yang bersedia jadi juru tulis karena adanya imbalan yang diperoleh, dan sering dilakukan hanya sebagai kegiatan sambilan dari kegiatan utama menjaga kedainya. Kondisi ini benar-benar dimanfaatkan oleh bandar untuk memperoleh keuntungan besar dari permainan judi togel.

Perkembangan Teknologi Informasi. Faktor lain yang mendukung kelancaran permainan judi togel adalah perkembangan teknologi informasi di tengah-tengah masyarakat, yang kemudian digunakan sebagai sarana untuk mempermudah penyebaran informasi. Perkembangan teknologi informasi juga benar-benar dimanfaatkan dalam komunikasi judi togel. Pemain judi dapat dengan mudah bertanya kepada temannya angka berapa yang harus dipasang. Pemesanan angka taruhan juga dapat dilakukan melalui HP ke juru tulis berdasarkan saling percaya atas pembayarannya. Demikian juga dengan juru tulis dapat menghubungi para pelanggannya untuk segera memasang taruhan sebagai bentuk dorongan untuk tetap ikut bermain judi.

Lemahnya Pengawasan Aparat. Peraturan hukum tentu sulit ditegakkan jika tidak disertai dengan pengawasan yang memadai. Dalam hal judi togel, aparat kepolisian sebagai penegak hukum seharusnya berperan melakukan pengawasan terhadap aktivitas masyarakat, tetapi ternyata pengawasan yang dilakukan masih tergolong lemah sehingga mendorong masyarakat untuk melanggar hukum perjudian. Kelemahan pengawasan juga mendorong 
masyarakat untuk tetap mengikuti permainan judi togel. Pendapat tersebut sejalan dengan penelitian Ella Gusrival yang menyatakan para pelaku judi togel tidak begitu takut untuk melakukan judi togel selain main judi togel lebih praktis dan lebih mudah, sanksi yang dikeluarkan tidak terlalu berat cuma sekedar menakuti dan mengertak pelaku judi togel tersebut, dan ketegasan dari tokoh masyarakat tidak terlalu kuat karena terbukti masalah judi togel itu masih ada dan tetap dilaksanakan oleh sebagian anggota masyarakat (Gusrival, 2015).

Selama jurtul dan bandar masih ada, maka permainan tersebut tidak akan berhenti, sehingga seharusnya tindakan pengawasan oleh aparat kepolisian lebih terarah kepada para jurtul dan bandarnya. Tetapi kemampuan kepolisian dalam melakukan pengawasan juga relatif kurang, karena keterbatasan personil serta keterbatasan sarana dan prasarana yang tersedia. Tidak memungkinkan bagi kepolisian untuk secara terus menerus mengawasi lingkungan masyarakat yang begitu luas, padahal tugas-tugas kepolisian yang lain juga relatif banyak.

\section{Faktor-faktor yang Mempengaruhi Penegakan Hukum terhadap Tindak Pidana Perjudian Toto Gelap}

Faktor hukum. Dalam penegakan hukum terhadap tindak pidana perjudian toto gelap perlu dicantumkannya hukuman minimal dalam KUHP sehingga hakim tidak dapat membuat hukuman yang jauh lebih rendah dari ancaman pidananya. Dalam kasus ini hakim hanya menjatuhkan hukuman 1 bulan 6 hari, jauh dari ancaman pidananya selama 4 tahun penjara (Zulyadi, 2020).

Faktor masyarakat. Masyarakat sebagai orang paling dekat dengan para pelaku perjudian tentu sangat mengenal dan mengetahui kapan suatu perjudian biasanya dilaksanakan, dan dimana dilaksanakan. Semua informasi tersebut sangat penting dalam penanggulangan perjudian, sehingga kepolisian sangat berharap adanya kerjasama masyarakat sebagai sumber informasi. Tetapi peran serta masyarakat dalam memberi informasi tergolong sangat rendah. Masyarakat jarang bersedia memberikan informasi atau memberi laporan mengenai aktivitas perjudian di lingkungannya. Kepolisian tidak dapat berharap terlalu banyak kepada masyarakat, sehingga kepolisian lebih mengandalkan pengamatan sendiri pada saat melakukan pengawasan. Sulitnya mendapat informasi dari masyarakat disebabkan masyarakat justru berusaha melindungi pelaku perjudian toto gelap.

Faktor budaya. Berdasarkan faktor budaya, kendala penegakan hukum perjudian toto gelap akibat terjadinya bocoran informasi, dimana ada budaya di masyarakat untuk segera menyebarkan dan menyampaikan kepada orang-orang yang sedang bermain judi kalau polisi akan melakukan penggerebekan, padahal kepolisian telah mempunyai rencana atau sedang bergerak ke tempat yang dimaksud.

Faktor sarana dan fasilitas. Sarana dan prasarana adalah semua fasilitas yang dibutuhkan pihak penegak hukum dalam pelaksanaan pekerjaan, baik yang digunakan secara langsung dalam pekerjaan maupun yang merupakan fasilitas pendukung pelaksanaan pekerjaan. Dalam penanganan perjudian, sarana dan prasarana utama yang digunakan pihak kepolisian adalah kenderaan bermotor, tetapi jumlah yang tersedia tidak mencukupi. kendala kenderaan yang kurang layak juga menyebabkan tugas patroli terkendala. Waktu patroli yang sebenarnya jarang dapat tersedia tidak dapat benar-benar terlaksana karena kenderaan tidak dalam kondisi siap untuk digunakan. Hal ini tentu mengganggu penanggulangan perjudian sehingga perlu keseriusan untuk menyediakan anggara untuk sarana dan prasarana.

Faktor penegak hukum. Kelancaran tugas kepolisian tentu sangat tergantung kepada jumlah anggota personil yang dapat dikerahkan untuk pelaksanaan tugas. Tetapi masalah yang sering muncul adalah bahwa jumlah anggota kepolisian selalu tidak sebanding dengan tugastugas yang harus dilakukan, sehingga banyak pekerjaan menjadi harus ditunda. Jumlah anggota kepolisian yang tidak sebanding dengan banyaknya pekerjaan kepolisian, maka polisi sering mengabaikan pengawasan terhadap aktivitas masyarakat yang melanggar undang-undang.

\section{SIMPULAN}

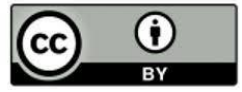


Faktor-faktor yang mendorong terjadinya tindak pidana perjudian di Kabupaten Deli Serdang adalah: adanya harapan mendapatkan kemenangan, adanya pengaruh lingkungan, judi togel mudah dilakukan oleh semua orang, tidak membutuhkan waktu banyak untuk melakukannya, juru tulis togel tersedia di banyak tempat, perkembangan teknologi informasi memudahkan pemain mengirimkan tebakan angka judi togel, serta lemahnya pengawasan oleh aparat kepolisian. Penegakan hukum terhadap perjudian jenis togel di Pengadilan Negeri Lubuk Pakam masih kurang tegas. Faktor-faktor yang mempengaruhi penegakan hukum terhadap tindak pidana perjudian toto gelap dianalisis menurut teori Soerjono Soekanto yaitu faktor hukum tindak pidana perjudian toto gelap perlu dicantumkannya hukuman minimal dalam KUHP, faktor masyarakat bahwa masyarakat jarang bersedia memberikan informasi atau memberi laporan mengenai aktivitas perjudian di lingkungannya, faktor budaya dimana kendala penegakan hukum perjudian toto gelap akibat terjadinya bocoran informasi, faktor sarana dan fasilitas dalam penanganan perjudian kenderaan yang digunakan tidak dalam kondisi siap untuk digunakan, faktor penegak hukum dimana jumlah anggota kepolisian selalu tidak sebanding dengan tugas-tugas yang harus dilakukan.

\section{DAFTAR PUSTAKA}

Abidin, A.Z. (2016). Hukum Pidana 1, Jakarta: Sinar Grafika. Alam, A.S. (2010). Pengantar Kriminologi. Makassar: Pustaka Refleksi Books.

Arif, B.N. (2002). Bunga Rampai Kebijakan Hukum Pidana. Bandung: Citra Aditya Bakti.

Ashshofa, B. (2006). Metodologi Penelitian Hukum. Jakarta: Rineka Cipta..

Charzawi, A. (2005). Tindak Pidana Mengenai Kesopanan. Jakarta: Raja Grafindo Persada.

Daliyo, J.B. (2011). Pengantar Hukum Indonesia. Jakarta: Prenhalindo.

Dekdipbud. (20150. Kamus Besar Bahasa Indonesia. Jakarta: Balai Pustaka.

Departemen Pendidikan Nasional. (2008) Kamus Besar Bahasa Indonesia Pusat Bahasa. Jakarta: Gramedia Pustaka Utama.

Djamali, A. (2013). Pengantar Hukum Indonesia. Jakarta: Raja Grafindo Persada.

Ediwarman. (2016). Monograf Metode Penelitian Hukum (Panduan Penulisan Skripsi, Tesis, dan Disertasi). Medan: Genta Publishing.

Huda, C. (2015). Dari Tiada Perbuatan Tanpa Kesalahan Menuju Kepada Tiada Pertanggungjawaban Pidana Tanpa Kesalahan. Jakarta: Kencana.

Ibrahim, J. (2006). Teori Dan Metedologi Penelitian Hukum Normatif. Jakarta: Pustaka Pelajar.

Lamintang, P.A.F. (2013). Dasar-dasar Hukum Pidana Indonesia. Bandung: Citra Aditya Bakti.

Lubis, M.S. (2014). Filsafat Ilmu dan Penelitian. Bandung: Mandar Maju.

Marpaung, L. (2015) Hukum Pidana Bagian Khusus. Jakarta: Sinar Grafika.

Moeljatno. (2016). Asas-asas Hukum Pidana. Jakarta:Rineka Cipta.

Muladi. (2002). Hak Asasi Manusia dan Reformasi Hukum di Indonesia, Jakarta: The Habibie Center.

Muladi. (2014). Hak Asasi Manusia, Politik dan Sistem Peradilan Pidana. Semarang: BP Undip.

Arief, B.N. (2008). Teori-Teori dan Kebijakan Pidana. Bandung: Alumni.

Poernomo, B. (2012) Asas-Asas Hukum Pidana. Jakarta: Ghalia Indonesia.

Prodjodikoro, W. (2003). Tindak-Tindak Pidana Tertentu di Indonesia. Bandung: Refika Aditama.

Reksodiputro, M. (2012). Sistem Peradilan Pidana (Peran Penegak Hukum Melawan Kejahatan), Pusat Pelayanan Keadilan dan Pengabdian Hukum. Jakarta: Universitas Indonesia.

Santoso, T. (2012). Asas-Asas Hukum Pidana. Jakarta: Sinar Grafika.

Soekanto, S. (2010). Faktor-faktor yang Mempengaruhi Penegakan Hukum. Jakarta: UI Pres.

Soesilo. (2005). Kitab Undang-Undang Hukum Pidana Serta Komentar-Komentarnya Lengkap Pasal Demi Pasal. Bogor: Politeia.

Sudarto. (2014). Kapita Selekta Hukum Pidana. Bandung: Alumni.

Sudarto. (2006). Hukum dan Hukum Pidana. Bandung: Alumni.

Zulyadi, S. (2020). Kerangka Teori Dalam Penelitian Hukum. Medan; Enam Media.

Undang-Undang Republik Indonesia Nomor 2 Tahun 2002 Tentang Kepolisian Negara Republik Indonesia. Undang-Undang No. 7 Tahun 1974 tentang Penertiban Perjudian.

Kitab Undang-Undang Hukum Pidana (KUHP)

Kitab Undang-Undang Hukum Acara Pidana (KUHAP)

Peraturan Pemerintah No. 9 Tahun 1981 tentang Pelaksanaan Undang-Undang No. 7 Tahun 1974 tentang Penertiban Perjudian.

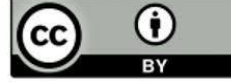


https://sumut.inews.id/berita/jadi-bandar-togel-tukang-jahit-di-medan-ditangkappolisi $+\& \mathrm{~cd}=1 \& \mathrm{hl}=\mathrm{id} \& \mathrm{ct}=\mathrm{clnk} \& \mathrm{gl}=\mathrm{id}$, diakses pada tanggal $200 \mathrm{ktober} 2020$.

https://www.sumut24.co/ditangkap-unit-reskrim-polsek-medan-baru-jurtul-togel-terancam-7-tahunpenjara, diakses pada tanggal 200ktober 2020.

https://www.wajahnusantara.com/buru-pemain-judi-togel-polisi-kembali-ciduk-2-pelaku, diakses pada tanggal 200ktober 2020.

https://sumutpos.co/2020/01/15/jurtul-dan-tukang-rekap-kim-ditangkap, diakses pada tanggal 200ktober 2020.

http://gomedan.co.id/2021/01/04/judi-togel-bebas-beroperasi-di-deli-serdang diakses pada tanggal 2Februari 2021.

https://id.m.wikipedia.org/wiki/perjudian diakses pada tanggal 1 Februari 2021.

Papu, J, Perilaku Berjudi, http://www.e-psikologi.com/epsi/sosial.asp, diakses pada tanggal 1 Februari 2021. 